Aquaculture

\title{
Use of a mixture of vegetal (Jatropha curcas) and animal (fish silage) byproducts as protein source in shrimp (Litopenaeus vannamei) diets
}

\author{
Hervey Rodríguez-González ${ }^{1}$ iD, Martín R. López-Aguilar ${ }^{1}$, Jorge Fonseca-Madrigal², Carlos A. \\ Martínez-Palacios ${ }^{2}$, Manuel García-Ulloa ${ }^{1 *}$ (iD \\ 1 Instituto Politécnico Nacional IPN, Centro Interdisciplinario de Investigación para el Desarrollo Integral Regional CIIDIR-Unidad Sinaloa, \\ Departamento de Acuacultura, Guasave, Sinaloa, México. \\ ${ }^{2}$ Instituto de Investigaciones Agropecuarias y Forestales IIAF, Universidad Michoacana de San Nicolás de Hidalgo, Morelia, Michoacán, México.
}

\begin{abstract}
This study evaluated growth responses of white shrimp Litopenaeus vannamei by testing different combinations of Jatropha curcas kernel meal (JCK) and tilapia waste silage (FS) as dietary protein sources under laboratory and pond conditions. A reference diet (RD) based on fish meal was elaborated to contain $35 \%$ crude protein and $434 \mathrm{kcal} / \mathrm{g}$; then, five isoproteic and isoenergetic experimental diets were formulated from RD with different FS/JCK proportions as follows: $75 \% \mathrm{FS} / 0 \% \mathrm{JCK} ; 56.25 \% \mathrm{FS} / 13.25 \% \mathrm{JCK} ; 26.5 \% \mathrm{FS} / 30.89 \% \mathrm{JCK} ; 18.75 \% \mathrm{FS} / 39.75 \% \mathrm{JCK}$; and $0 \% \mathrm{FS} / 53 \% \mathrm{JCK}$. For the laboratory trial, shrimp $(2.90 \mathrm{~g})$ were stocked at $10 \mathrm{~m}^{2}$ in an indoor recirculating system during 90 days. There were differences among the growth parameters of diets. Mean weight gain fluctuated from $6.71 \pm 0.61 \mathrm{~g}$ observed for the shrimp fed the $75 \% \mathrm{FS} /$ $0 \% \mathrm{JCK}$ diet, to $9.70 \pm 0.61 \mathrm{~g}$ for the group fed the RD. The RD and $18.75 \% \mathrm{FS} / 39.75 \% \mathrm{JCK}$ diet obtained the highest mean final weight (above $12 \mathrm{~g}$ ), weight gain (above $9 \mathrm{~g}$ ), and specific growth rate values (above 1.6\%/day). Average final survival was $90.97 \%$. The RD and $18.75 \% \mathrm{FS} / 39.75 \% \mathrm{JCK}$ diets were used for the pond trial. Shrimp $(0.49 \mathrm{~g})$ were stocked at $10 \mathrm{~m}^{2}$ within $1-\mathrm{m}^{3} \mathrm{cages}$ into the pond for 35 days. Weight gain (3.47 g) and survival (93.33\%) of shrimps were similar between the diets. Quadratic equations with the laboratory data indicated that the maximum responses for growth parameters correspond to FS and JKC inclusion levels in the range of 27.83 to $29.00 \%$, and 32.25 to $33.64 \%$, respectively. A combination of $18.75 \% \mathrm{FS} / 39.75 \% \mathrm{JCK}$ meals as protein source is a potential alternative to effectively substitute FM in practical diets for L. vannamei at the studied ages under both laboratory and pond conditions.
\end{abstract}

Key Words: alternative diets, aquafeeds, growth performance, survival, white shrimp

\section{Introduction}

Traditionally, fish meal (FM) has been the main source of dietary protein for fish and shrimp. In recent years, its increasing cost, decreasing availability in the market, and poor quality have encouraged the development of several studies about its partial or complete replacement with alternative protein sources (Kaushik et al., 1995; Fournier et al., 2004). Soybean meal (SBM) is currently the most commonly used plant protein source in fish feeds (Yue and Zhou, 2009), but its price has increased sharply. Nowadays, maize is used as an energy source for fish to reduce feed costs but at the same time it is utilized to satisfy the rising demand of the fast-growing biofuel industry (Azaza et al.,

Received: June 13, 2017

Accepted: February 22, 2018

*Corresponding author: turbotuag@hotmail.com

Copyright (c) 2018 Sociedade Brasileira de Zootecnia. This is an Open Access article distributed under the terms of the Creative Commons Attribution License (http://creativecommons.org/licenses/by/4.0/), which permits unrestricted use, distribution, and reproduction in any medium, provided the original work is properly cited.
2009). Therefore, searching for new aquaculture feedstuff derived from both vegetal and animal byproducts as protein sources is a priority.

Jatropha curcas is a multipurpose and drought-resistant tree, widespread throughout the tropics and subtropics. It is a hardy plant, thrives on degraded land, and requires limited amounts of nutrients and water. The International Jatropha Organization has projected that, in 2017, there will be around 32.72 million hectares of land cultivated worldwide with $J$. curcas, producing 160 million tons of seeds, and $95 \%$ of its total production will be in Asia (Siang, 2009). Jatropha seeds have been extensively investigated as a source of oil. The seed kernel contains about $60 \%$ oil that can be converted into high-quality biodiesel upon trans-esterification and used as a substitute for diesel fuel (Makkar et al., 2007). The kernel meal obtained after oil extraction is an excellent source of nutrients and contains 58-62\% crude protein (Makkar et al., 2008). Except for lysine, the levels of essential amino acids in $J$. curcas kernel meal are higher than in soybean meal. On the other hand, the presence of antinutrients such as trypsin inhibitor, lectin 
and phytate (Makkar et al., 2008), and toxic components such as phorbol esters (Makkar and Becker, 2009) restrict its use in fish feed. However, nontoxic $J$. curcas genotypes that do not contain phorbol esters have been reported in Mexico (Makkar et al., 2008). Jatropha plant can yield up to $4 \mathrm{t}$ seed per year from a 1-ha plantation, which can produce approximately $1 \mathrm{t}$ of kernel meal rich in protein (Makkar and Becker, 2009). This means that there is a possibility to produce enough Jatropha kernel meal to partially support the growing aquaculture industry demand.

The use of fish silage as a substitute of FM is an alternative of low-cost nutrients. In general, $60 \%$ of the fish captured worldwide is commercialized or processed with adding value (frozen, canned, etc.), producing a considerable amount of organic waste. Also, the aquaculture industry is the largest contributor to the increase of fish production in the world, generating important amounts of fish waste. Thus, the use of fish waste silage contributes additionally to minimize the environmental problems derived by the fish waste discharges to nature. There are successful reports that recommend the use of fish waste silage in the feeding of Clarias gariepinus (Fagbenro et al., 1994), O. niloticus (El-Hakim et al., 2007; Soltan and El-Laithy, 2008), Salmo salar (Heras et al., 1994), Haliotis fulgens (Viana et al., 1999), Arapaima gigas (Honczaryk and Maeda, 1998), and Ictalurus punctatus (Haard, 1992), among other aquatic species.

According to Álvarez et al. (2007) and Suárez et al. (2009), the combination of different protein sources substituting FM favors the protein efficiency ratio and growth performance of aquatic organisms since the ingredient profiles such as essential amino acids and fatty acids could properly meet the fish and shellfish dietary requirements. This study reported growth responses of L. vannamei by adding different combinations of $J$. curcas kernel meal and fish waste silage as protein sources in shrimp diets, under laboratory and pond conditions.

\section{Material and Methods}

Seeds of $J$. curcas were obtained from an experimental field, located in Mazatlán, Sinaloa, Mexico (2314'29" N and $106^{\circ} 24^{\prime} 35^{\prime \prime} \mathrm{W}$ ). The seeds were broken with physical pressure and dehulled. The inner part was dried and grounded to obtain a meal. Since the lipid content of the $J$. curcas meal was high $(49.66 \pm 0.37 \%)$, a proportion of 1.5:10 p:v of hexane was dissolved with the meal, filtered, and dried, to finally be stored at $4{ }^{\circ} \mathrm{C}$ before being used.

Fish silage was prepared using tilapia byproducts (non-edible parts: heads, skin, tail, bones, viscera) obtained from a local processing fish plant (Guasave 400, Guasave, Sinaloa, Mexico; $25^{\circ} 34^{\prime} 28^{\prime \prime} \mathrm{N}$ and $\left.108^{\circ} 28^{\prime} 16^{\prime \prime} \mathrm{W}\right)$.

Fish byproducts were minced (Torrey ${ }^{\circledR}, \mathrm{M}-22 \mathrm{R}$ ), distributed into plastic bags, and frozen $\left(-20^{\circ} \mathrm{C}\right)$ before use. Fish silage was prepared in 5-L plastic containers by adding $1 \mathrm{~kg}$ of fish byproduct and $15 \mathrm{~mL}$ of formic acid $(85 \%$, Food grade). The substrate was mixed to reduce the $\mathrm{pH}$ up to 3.8-4.0 (Fagbenro and Jauncey, 1993) and then incubated under anaerobic conditions for seven days. The temperature range during the production of fish silage was $24-26{ }^{\circ} \mathrm{C}$. After that, formic acid was gradually added during the first two days of ensiling to maintain $\mathrm{pH}$ below 4.0. Finally, the silage was dried in a draft oven at $60{ }^{\circ} \mathrm{C}$ for $24 \mathrm{~h}$ and ground before being incorporated to the experimental diets. The $\mathrm{pH}$ of the FS was adjusted according to Gallardo et al. (2012).

The proximate composition of the ingredients and diets ( $\mathrm{g} / \mathrm{kg}$ dry matter) was determined according to the Association of Official Analytical Chemists (AOAC, 1990) methods for ash (Section 942.05), crude fiber (Section 978.10), and moisture (Section 930.15). Crude protein (CP) was determined by the micro-Kjeldahl method (Section 976.05) and crude lipids were determined by AOAC method (Section 920.39; Table 1). Amino acid composition of the JCK and FS was determined according to AOAC (1990) (Table 2).

A reference diet (RD) based on FM was elaborated containing $35 \% \mathrm{CP}$ and $434 \mathrm{kcal} / \mathrm{g}$ of diet. From RD, five more diets were formulated (Houser and Akiyama, 1997) incorporating different proportions of mixtures of FS/JCK to create isoproteic an isoenergetic diets as follows: $75 \% \quad \mathrm{FS} / 0 \% \mathrm{JCK} ; \quad 56.25 \% \quad \mathrm{FS} / 13.25 \% \mathrm{JCK} ; \quad 26.5 \% \mathrm{FS} /$ $30.89 \% \mathrm{JCK} ; 18.75 \% \mathrm{FS} / 39.75 \% \mathrm{JCK}$; and $0 \% \mathrm{FS} / 53 \% \mathrm{JCK}$. The wheat meal was used as filler and energy source when experimental diets were formulated (Table 3).

Feedstuffs were ground (Grindmaster, Model 505, Louisville, KY, USA), sieved (No. 60, FIIC, SA de CV, MX) through a $100-\mu$ sieve, and mixed in a blender (KitchenAid, Model 600, Benson Harbor, MI, USA) for $30 \mathrm{~min}$. Fish oil and soy lecithin were mixed and later gradually added to the dry mix, as well as water to make a stiff dough. The

Table 1 - Proximate composition (g/kg, dry matter) of Jatropha curcas and fish silage (mean $\pm \mathrm{SD} ; \mathrm{n}=3$ )

\begin{tabular}{lcc}
\hline & Jatropha curcas & Fish silage \\
\hline Moisture & $40.2 \pm 0.2$ & $41.4 \pm 3.7$ \\
Protein & $553.2 \pm 1.4$ & $422.9 \pm 18.0$ \\
Lipid & $151.0 \pm 4.0$ & $265.9 \pm 9.0$ \\
Ash & $55.7 \pm 0.8$ & $180.1 \pm 2.6$ \\
Fiber & $49.3 \pm 0.3$ & $1.8 \pm 0.1$ \\
Nitrogen-free extract & 190.8 & 129.3 \\
Energy (kcal/g) & $423.99 \pm 2.8$ & $426.90 \pm 4.3$ \\
\hline SD - standard deviation. & &
\end{tabular}


wet mixture was pressure-pelleted through a meat grinder (Torrey ${ }^{\circledR}, \mathrm{M}-22 \mathrm{R}$ ), steamed for $5 \mathrm{~min}$, and dried in a draft oven at $60{ }^{\circ} \mathrm{C}$ overnight, or until pellets contained less than $10 \%$ moisture. Finally, diets were broken at 3-4 mm size and stored in plastic bags at $5{ }^{\circ} \mathrm{C}$ until use.

Shrimp were obtained from a local farm (Acuícola Camaronera Styl, Guasave, Sinaloa, Mexico; 2523'42"N and $108^{\circ} 32^{\prime} 46^{\prime \prime} \mathrm{W}$ ) and transported to the experimental acclimation tank, where animals were sorted to homogenize shrimp sizes.

After acclimation, juveniles $(2.90 \pm 0.06 \mathrm{~g})$ were randomly selected, weighed, and stocked at $10 \mathrm{shrimp} / \mathrm{m}^{2}$ in 60-L plastic indoor tanks, connected to a recirculating system, in which $50 \%$ of the total water volume of each tank was exchanged daily. Diets were tested with three

Table 2 - Amino acid composition ( $\mathrm{g} / \mathrm{kg}$, dry matter) of the experimental meals

\begin{tabular}{lcc}
\hline & Fish silage & Jatropha curcas \\
\hline Methionine & 0.98 & 1.44 \\
Lysine & 3.47 & 5.43 \\
Threonine & 2.32 & 4.56 \\
Arginine & 2.23 & 8.07 \\
Isoleucine & 1.77 & 6.34 \\
Leucine & 3.09 & 9.28 \\
Valine & 1.93 & 1.23 \\
Histidine & $*$ & 2.39 \\
Phenylalanine & 1.60 & 5.81 \\
Tyrosine & 1.17 & 9.34 \\
Cysteine & 6.39 & 17.00
\end{tabular}

replicates by randomly assigning them to the tanks. All water parameters were measured daily. The temperature was maintained at $28.0 \pm 1{ }^{\circ} \mathrm{C}$ by introducing an aquarium heater $(100 \mathrm{~W})$ into the water inlet container, and constant aeration was supplied to each tank with a stone diffuser connected to a 2-Hp blower to keep the dissolved oxygen concentration above $4.0 \mathrm{mg} / \mathrm{L}$. Salinity ( $35.0 \pm 0.5 \mathrm{PSU})$ and $\mathrm{pH}$ (7.66 to 7.98$)$ were measured daily with a hand refractometer (model 300011, Sper Scientific, USA) and a $\mathrm{pH}$ meter, respectively. Photoperiod (12 h light:12 h dark) was maintained with artificial light (white daylight). Shrimp were fed to satiation twice daily $(09.00$ and $17.00 \mathrm{~h})$ to ensure that their growth was properly expressed by the effect of the diets. Feed waste was siphoned $2 \mathrm{~h}$ after each feeding and feces were siphoned daily. The RD and experimental diets were offered to shrimp during one week before starting the experiment, which lasted 90 days.

The second study under pond conditions was carried out to compare the effect of the experimental diet that obtained the best results in the previous laboratory trial and the $\mathrm{RD}$, but on a larger scale. For that, eight plastic cages (500 $\mu \mathrm{m}$ mesh diameter) of $1 \mathrm{~m}^{3}$ were placed into a 3.5-ha pond (Ejido La Culebra, Sinaloa, Mexico: 25²3'42" N and $108^{\circ} 32^{\prime} 46^{\prime \prime} \mathrm{W}$ ). Cages were attached to a row, keeping $1-\mathrm{m}$ separation between them, from the center and along the pond. To ensure homogenized movement of water, the row was placed perpendicular to the main water flow of the pond. Diets were tested with four replicates by randomly

Table 3 - Ingredient composition ( $\mathrm{g} / \mathrm{kg}$, dry matter) and proximate analysis $(\mathrm{g} / \mathrm{kg}$, dry matter) of six experimental diets for juvenile Litopenaeus vannamei $($ mean $\pm \mathrm{SD}, \mathrm{n}=3)$

\begin{tabular}{|c|c|c|c|c|c|c|}
\hline Ingredient & Reference diet & Diet 1 & Diet 2 & Diet 3 & Diet 4 & Diet 5 \\
\hline Fish meal $^{1}$ & 430 & 0 & 0 & 0 & 0 & 0 \\
\hline Fish waste silage & 0 & 750 & 562.5 & 375 & 187.5 & 0 \\
\hline Jatropha curcas & 0 & 0 & 132.5 & 265 & 397.5 & 530 \\
\hline Wheat meal & 428.9 & 208.9 & 263.9 & 308.9 & 333.9 & 368.9 \\
\hline Binder (grenetine) ${ }^{2}$ & 40 & 40 & 40 & 40 & 40 & 40 \\
\hline Fish oil & 50 & 0 & 0 & 10 & 40 & 60 \\
\hline Soybean lecithin & 50 & 0 & 0 & 0 & 0 & 0 \\
\hline Vitamin premix ${ }^{3}$ & 0.1 & 0.1 & 0.1 & 0.1 & 0.1 & 0.1 \\
\hline Mineral premix ${ }^{4}$ & 1.0 & 1.0 & 1.0 & 1.0 & 1.0 & 1.0 \\
\hline Moisture & $88.0 \pm 1.3$ & $111.0 \pm 3.0$ & $116.0 \pm 3.9$ & $145.5 \pm 1.3$ & $100.3 \pm 0.4$ & $96.7 \pm 1.0$ \\
\hline Protein & $346.8 \pm 4.4$ & $347.1 \pm 1.6$ & $352.0 \pm 1.9$ & $358.0 \pm 1.7$ & $359.0 \pm 0.8$ & $347.2 \pm 1.4$ \\
\hline Lipid & $152.5 \pm 2.2$ & $199.6 \pm 1.3$ & $186.2 \pm 1.5$ & $143.1 \pm 1.2$ & $144.8 \pm 1.5$ & $138.0 \pm 1.0$ \\
\hline Ash & $84.0 \pm 1.5$ & $71.8 \pm 0.5$ & $69.9 \pm 0.6$ & $68.0 \pm 1.2$ & $63.1 \pm 1.9$ & $60.0 \pm 0.2$ \\
\hline Fiber & $1.3 \pm 0.6$ & $2.3 \pm 0.3$ & $4.3 \pm 0.6$ & $13.3 \pm 1.5$ & $16.0 \pm 0.6$ & $21.0 \pm 2.0$ \\
\hline Nitrogen-free extract & 415.4 & 379.2 & 387.6 & 417.6 & 417.1 & 413.8 \\
\hline Energy $(\mathrm{kcal} / \mathrm{g})$ & $428.58 \pm 3.5$ & $448.23 \pm 3.5$ & $443.99 \pm 2.6$ & $427.42 \pm 3.8$ & $428.88 \pm 0.9$ & $425.70 \pm 2.6$ \\
\hline
\end{tabular}

FS - fish silage; JCK - Jatropha curcas kernel meal.

Diet 1: 75\% FS/0\%JCK; Diet 2: 56.25\% FS/13.25\%JCK; Diet 3: 26.5\%FS/30.89\%JCK; Diet 4: 18.75\%FS/39.75\%JCK; Diet 5: 0\%FS/53\%JCK.

${ }^{1}$ Nutrimentos Acuícolas Azteca ${ }^{\circledR}$, Guadalajara, Jalisco, México. Proximate analysis: moisture, 8.80\%; protein, $62.96 \%$; lipid, $12.83 \%$; ash, $16.5 \%$; fiber, $0.06 \%$; NFE, 7.66\%. Amino acid composition: methionine, $2.4 \%$; lysine, $6.7 \%$; threonine, $2.3 \%$; arginine, $6.6 \%$; isoleucine $4.9 \%$; leucine, $6.5 \%$; valine, $4.5 \%$; histidine, $3.5 \%$; phenylalanine $3.9 \%$; tyrosine, $3.6 \%$.

${ }^{2}$ Commercial gelatin (De Muylder et al., 2008).

${ }^{3}$ Vitamin premix (units in $\mathrm{mg} / \mathrm{kg}$, except when indicated): retinol, $5000 \mathrm{IU}$; cholecalciferol, $4000 \mathrm{UI}$; $\alpha$-tocopherol acetate, 100 ; menadione, 5; thiamin, 60; riboflabin, 25; pyridoxine HCL, 50; pantothenic acid, 75; niacin, 40; biotin, 1; inositol, 400; cyanocobalamin, 0.2; folic acid, 10.

${ }^{4}$ Mineral premix (g/kg diet): $\mathrm{KCl}, 0.5 ; \mathrm{MgSO}_{4} \cdot 7 \mathrm{H}_{2} \mathrm{O}, 0.5 ; \mathrm{ZnSO}_{4} \cdot 7 \mathrm{H}_{2} \mathrm{O}, 0.09 ; \mathrm{MnCl}_{2} \cdot 4 \mathrm{H}_{2} \mathrm{O}, 0.0234 ; \mathrm{CuSO}_{4} \cdot 5 \mathrm{H}_{2} \mathrm{O}, 0.005 ; \mathrm{KI}_{2} 0.0005 ; \mathrm{CoCl}_{2} \cdot 2 \mathrm{H}_{2} \mathrm{O}, 0.00025 ; \mathrm{Na}_{2} \mathrm{HPO}_{4}, 2.37$. 
assigning them to the cages. Juveniles $(0.49 \pm 0.01 \mathrm{~g})$ were weighed and stocked adjusting the initial density at 10 shrimp $/ \mathrm{m}^{2}$. Weekly, water temperature $\left(30 \pm 1.5{ }^{\circ} \mathrm{C}\right)$ and dissolved oxygen $(3.2 \pm 0.5 \mathrm{mg} / \mathrm{L})$ were measured with an oxygen meter (YSI ${ }^{\circledR}$ Model 55, Yellow Springs, OH, USA), and salinity (38.0 \pm 0.5 PSU) with a hand refractometer (Sper Scientific ${ }^{\circledR}$, Scottsdale, AZ, USA). Cages were cleaned every three days with a soft brush. Daily, shrimp were fed twice to apparent satiation $(09.00$ and $17.00 \mathrm{~h})$. For that, a feeding tray of $20 \mathrm{~cm}$ diameter ( $2 \mathrm{~mm}$ mesh) tied and suspended into the cage with $30 \%$ of the feeding ration was used to observe the daily feed intake. The $70 \%$ of the feeding ration was distributed on the cage bottom. Shrimp were fed the RD and experimental diets during one week before starting the experiment, which lasted 35 days.

Total body weight (g) of shrimps reared in the laboratory was obtained every two weeks, whereas in the pond, shrimp were weighed weekly. Prior to weighing, shrimp were placed on absorbent paper to remove water excess. Weight gain (WG) was calculated as WG (g) = average final weight - average initial weight; and specific growth rate as SGR $(\%)=100 \times(\ln$ final weight $-\ln$ initial weight)/days of cultivation. Survival rate (S) was calculated as $\mathrm{S}(\%)=($ final number of shrimp per treatment/initial number of shrimp per treatment) $\times 100$.

Data were analyzed for normality and homoscedasticity with the Shaphiro-Wilk's and Bartlett's tests, respectively (Zar, 2010). One-way ANOVA was used to measure the effect of FS and JCK meals as factors. Individual differences between treatments were determined by Tukey's test (Zar, 2010) if a significant interaction between factors was detected. Percentages of survival were log-transformed (ln) before analysis. The Statistica 7.0 software (StatSoft, Tulsa, OK) was used to process the data. Significance was set at $\mathrm{P}<0.05$.

The most adequate inclusion of FS and JCK, based on maximum final weight, WG, and SGR of shrimp studied under laboratory conditions, was determined using quadratic equations (Shearer, 2000):

$$
\mathrm{y}=\mathrm{a}_{0}+\mathrm{a}_{1} \mathrm{FS}\left(\text { or JCK) }+\mathrm{a}_{2} \mathrm{FS}^{2}\left(\text { or } \mathrm{JCK}^{2}\right),\right.
$$

in which $\mathrm{y}$ is the response variable; $\mathrm{a}_{0}, \mathrm{a}_{1}$, and $\mathrm{a}_{2}$ are regression coefficients; and $\mathrm{FS}_{\max }\left(\right.$ or $\left.\mathrm{JCK}_{\max }\right)=-\mathrm{a}_{1}\left(2 \mathrm{a}_{2}\right)^{-1}$ estimates the inclusion of FS (or JCK) (\%) for maximum response.

\section{Results}

Except for the energy ( $425 \mathrm{kcal} / \mathrm{g}$ mean value), the proximal composition of the experimental ingredients
(Table 1) showed variation between all contents. Protein was higher than $42 \% \mathrm{CP}$ for both JCK and FS ingredients. Protein, fiber, and NFE contents were higher for JCK, and FS presented more lipid and ash content. The amino acid composition of the JCK meal displayed higher concentrations compared with those obtained for the FS meal, except for valine. Cysteine $(17.00 \mathrm{~g} / \mathrm{kg})$ and leucine $(9.28 \mathrm{~g} / \mathrm{kg})$ contents were three times higher for JCK. Histidine content in FS was not detected (Table 2). With respect to the dietary amino acid levels recommended for shrimp diet (Table 4) (Tacon et al., 1999; Fox et al., 2010; Nunes et al., 2014), the $75 \%$ FS $/ 0 \% J C K$ diet was deficient in arginine, isoleucine, histidine, and tyrosine; the $56.25 \%$ $\mathrm{FS} / 13.25 \% \mathrm{JCK}$ and $26.5 \% \mathrm{FS} / 30.89 \% \mathrm{JCK}$ dets in histidine; and $0 \% \mathrm{FS} / 53 \% \mathrm{JCK}$ diet in valine.

There were significant differences $(\mathrm{P}<0.05)$ among the treatments for final weight, WG, and SGR of shrimp reared under laboratory conditions (Table 5). Shrimps fed the $\mathrm{RD}$ obtained the highest mean values $(\mathrm{P}<0.05)$ for final weight, WG, and SGR $(12.68 \pm 0.59 \mathrm{~g}, 9.70 \pm 0.59 \mathrm{~g}$, and $1.61 \% / d$, respectively). Similar values were observed for the $18.75 \% \mathrm{FS} / 39.75 \% \mathrm{JCK}$ diet. Juveniles fed the $75 \% \mathrm{FS} /$ $0 \% \mathrm{JCK}$ diet registered the lowest overall growth results. Final survival was similar among the groups and fluctuated from $87.50 \pm 8.3 \%$ for the $75 \% \mathrm{FS} / 0 \% \mathrm{JCK}$ diet, to $95.83 \pm 8.3 \%$ obtained with the $26.5 \% \mathrm{FS} / 30.89 \% \mathrm{JCK}$ treatment. The regression analysis between dietary inclusion of FS and JCK with final weight, WG, and SGR of shrimp cultured in laboratory indicated significant correlation $(\mathrm{P}<0.05)$, in which the maximum responses of these growth parameters corresponded to FS and JCK inclusion levels in the range of 27.83 to $29 \%$ and 32.25 to $33.64 \%$, respectively (Figure 1 ).

Table 4 - Amino acid composition ( $\mathrm{g} / \mathrm{kg}$, dry matter) of experimental diets compared with a shrimp diet (35\% crude protein)

\begin{tabular}{lcccccc}
\hline Aminoacid & Diet 1 & Diet 2 & Diet 3 & Diet 4 & Diet 5 & $\begin{array}{c}\text { Recomended } \\
\text { dietary level }\end{array}$ \\
\hline Methionine & 0.74 & 0.74 & 0.75 & 0.75 & 0.76 & $0.74^{2}$ \\
Lysine & 2.60 & 2.67 & 2.74 & 2.81 & 2.88 & $2.10^{3}$ \\
Threonine & 1.74 & 1.91 & 2.08 & 2.25 & 2.42 & $1.40^{3}$ \\
Arginine & 1.74 & 2.37 & 3.01 & 3.64 & 4.28 & $2.32^{3}$ \\
Isoleucine & 1.33 & 1.84 & 2.34 & 2.85 & 3.36 & $1.59^{3}$ \\
Leucine & 2.32 & 2.97 & 3.62 & 4.27 & 4.92 & $1.70^{3}$ \\
Valine & 1.45 & 1.25 & 1.05 & 1.04 & 0.65 & $1.04^{1}$ \\
Histidine & $\mathrm{ND}$ & 0.32 & 0.63 & 0.95 & 1.27 & $0.80^{3}$ \\
Phenylalanine & 1.20 & 1.67 & 2.14 & 2.61 & 3.08 & $0.94^{1}$ \\
Tyrosine & 0.88 & 1.13 & 1.38 & 1.62 & 1.87 & $0.96^{1}$ \\
Cysteine & 4.79 & 5.86 & 6.92 & 7.99 & 90.5 & $30.0^{3}$ \\
\hline
\end{tabular}

FS - fish silage; JCK - Jatropha curcas kernel meal; ND - not determined. Diet 1: 75\% FS/0\%JCK; Diet 2: 56.25\% FS/13.25\%JCK; Diet 3: 26.5\%FS/30.89\%JCK; Diet 4: $18.75 \% \mathrm{FS} / 39.75 \% \mathrm{JCK}$; Diet 5: $0 \% \mathrm{FS} / 53 \% \mathrm{JCK}$.

${ }^{1}$ Tacon et al. (1999).

${ }^{2}$ Fox et al. (2010)

${ }^{3}$ Nunes et al. (2014) 

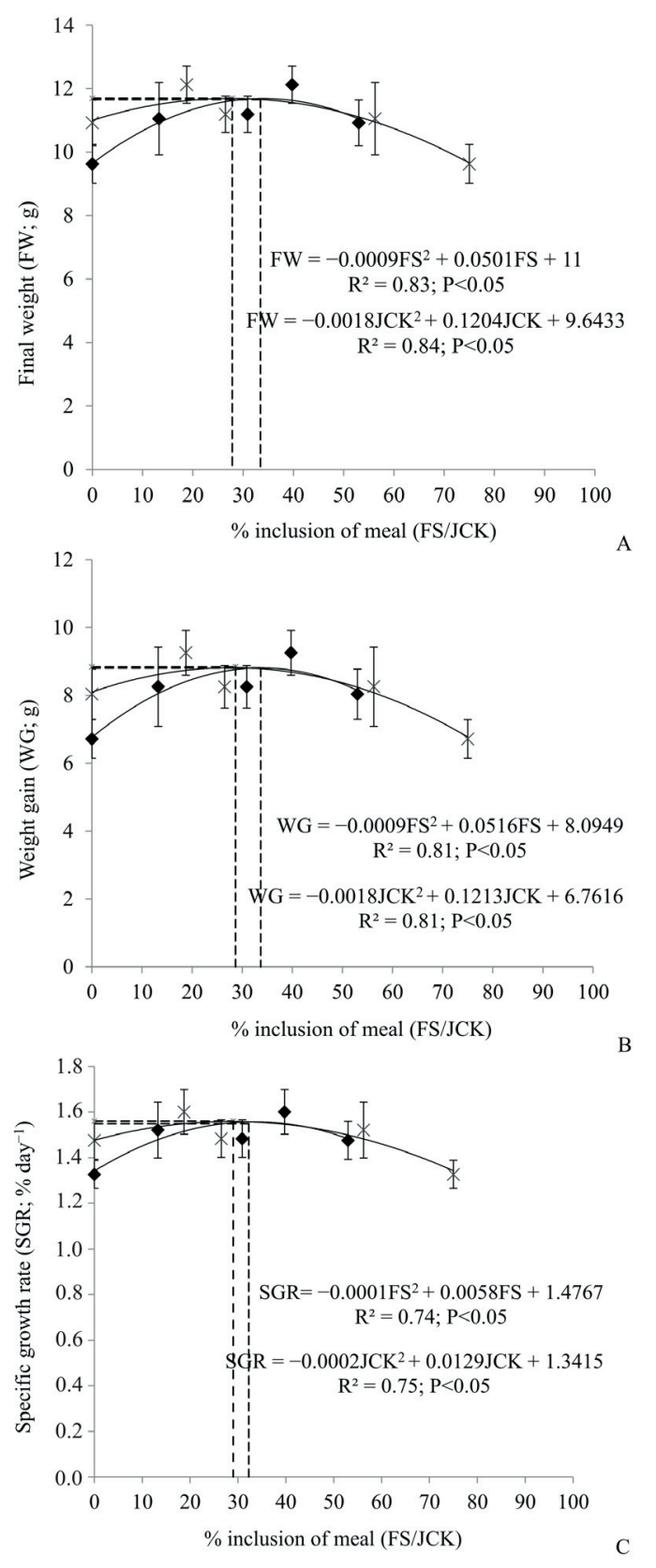

FS - fish silage; JCK - Jathropa curcas kernel meal; SE - standard error. The percentage of FS and JCK yielding maximum final weight, weight gain, and specific growth rate are indicated (dashed lines, $\times$ for FS, and $\bullet$ for JCK) (mean $\pm \mathrm{SE}$; $\mathrm{n}=35)$.

Figure 1 - Correlation of the mean final weight (A), weight gain (B), and specific growth rate (C) of shrimp Litopenaeus vannamei with FS/JCK dietary inclusion levels.
After 35 culture days in the pond, shrimps fed the RD and $18.75 \% \mathrm{FS} / 39.75 \% \mathrm{JCK}$ diet were similar $(\mathrm{P}>0.05)$ for the final weight, WG, SGR, and survival (Table 6).

\section{Discussion}

The combination of plant and animal byproducts as protein sources for partially or totally replacement of FM in shrimp diets represents a viable alternative to balance essential nutrient profiles (amino acids, fatty acids, vitamins, minerals). The results of both trials suggest that FM can be totally substituted for a mixture of FS/JCK meals without negative effects on shrimp performance. The growth observed in our study was typical of shrimp offered a high-quality practical diet under research conditions (Samocha et al., 2004; Hernández et al., 2008). Survival in the laboratory and pond trials was high, indicating good health condition of shrimp, adequacy of water quality parameters, and absence of nutrient deficiency in the diets. In general, there were no indications of the feed being rejected or poor in palatability, which was determined by visual observation.

There is no information available on the use of the FS/JCK mixture in aquafeeds; both ingredients have been studied separately. Fagbenro and Jauncey (1998) concluded that moist FS pellets were physically stable and highly digestible to Oreochromis niloticus, and Soltan and El-Laithy (2008) pointed out the possibility of replacing 30\% of CP by FS in tilapia diets reducing feed costs by $22.43 \%$. Stone et al. (1989) and Soltan and Tharwat (2006) successfully evaluated the inclusion of FS in diets of rainbow trout Salmo gairdneri and African catfish Clarias gariepinus, respectively. Kumar et al. (2010) and Nepal et al. (2010) included JCK in the diet of common carp (Ciprinus carpio) fingerlings, while Shamna et al. (2015) determined growth, nutrient utilization, and physio-metabolic responses of cyprinid Labeo rohita fingerlings fed J. curcas seed cake. To our understanding, so far, there are no reports using the FS/JCK dietary combination in shrimp diets. Similar to our

Table 5 - Mean final weight, weight gain, SGR, and survival of juvenile L. vannamei fed different diets based on a mixture of JCK and FS under laboratory conditions (mean $\pm \mathrm{SD} ; \mathrm{n}=3$ )

\begin{tabular}{|c|c|c|c|c|c|}
\hline Diet & Initial mean weight $(\mathrm{g})$ & Final mean weight $(\mathrm{g})$ & Weight gain $(\mathrm{g})$ & SGR (\%/day) & Survival (\%) \\
\hline Diet 1 & $2.91 \pm 0.09 \mathrm{a} *$ & $9.63 \pm 0.61 d$ & $6.71 \pm 0.57 \mathrm{~d}$ & $1.33 \pm 0.06 \mathrm{a}$ & $87.50 \pm 8.3 \mathrm{a}$ \\
\hline Diet 2 & $2.80 \pm 0.05 \mathrm{a}$ & $11.05 \pm 1.13 \mathrm{c}$ & $8.25 \pm 1.16 b c$ & $1.52 \pm 0.12 b$ & $87.50 \pm 15.9 \mathrm{a}$ \\
\hline Diet 3 & $2.94 \pm 0.09 \mathrm{a}$ & $11.19 \pm 0.57 \mathrm{bc}$ & $8.25 \pm 0.62 b c$ & $1.48 \pm 0.08 b$ & $95.83 \pm 8.3 \mathrm{a}$ \\
\hline Diet 4 & $2.87 \pm 0.18 \mathrm{a}$ & $12.12 \pm 0.58 \mathrm{ab}$ & $9.25 \pm 0.65 \mathrm{ab}$ & $1.60 \pm 0.09 b$ & $91.67 \pm 9.6 \mathrm{a}$ \\
\hline Diet 5 & $2.89 \pm 0.06 \mathrm{a}$ & $10.92 \pm 0.72 \mathrm{c}$ & $8.03 \pm 0.73 c$ & $1.48 \pm 0.08 b$ & $91.67 \pm 9.6 \mathrm{a}$ \\
\hline $\mathrm{RD}$ & $2.98 \pm 0.14 \mathrm{a}$ & $12.68 \pm 0.59 \mathrm{a}$ & $9.70 \pm 0.61 \mathrm{a}$ & $1.61 \pm 0.07 \mathrm{~b}$ & $91.67 \pm 16.6 \mathrm{a}$ \\
\hline
\end{tabular}

SGR - specific growth rate; JCK - Jatropha curcas kernel meal; FS - fish silage; SD - standard deviation; RD - reference diet.

Diet 1: 75\% FS/0\%JCK; Diet 2: 56.25\% FS/13.25\%JCK; Diet 3: 26.5\%FS/30.89\%JCK; Diet 4: 18.75\%FS/39.75\%JCK; Diet 5: 0\%FS/53\%JCK.

* Values in the same column with different letters are significantly different $(\mathrm{P}<0.05)$. 
Table 6 - Mean final weight, weight gain, and survival of juvenile L. vannamei fed the reference diet (RD) and Diet 4 in the pond (mean $\pm \mathrm{SD} ; \mathrm{n}=4)$

\begin{tabular}{lccccc}
\hline Diet & $\begin{array}{c}\text { Initial } \\
\text { weight }(\mathrm{g})\end{array}$ & $\begin{array}{c}\text { Final weight } \\
(\mathrm{g})\end{array}$ & $\begin{array}{c}\text { Weight gain } \\
(\mathrm{g})\end{array}$ & $\begin{array}{c}\text { SGR } \\
(\% / \text { day })\end{array}$ & $\begin{array}{c}\text { Survival } \\
(\%)\end{array}$ \\
\hline Diet 4 & $0.48 \pm 0.09$ & $3.92 \pm 0.56$ & $3.44 \pm 0.48$ & $6.03 \pm 0.29$ & $93.33 \pm 11.5$ \\
RD & $0.50 \pm 0.03$ & $4.01 \pm 0.06$ & $3.50 \pm 0.04$ & $5.92 \pm 0.16$ & $93.33 \pm 11.5$ \\
\hline
\end{tabular}

JCK - Jatropha curcas kernel meal; FS - fish silage; SD - standard deviation. Diet 4: $18.75 \% \mathrm{FS} / 39.75 \% \mathrm{JCK}$

work, Gallardo et al. (2012) offered FS, fish waste meal, and a combination of FS with SBM to white shrimp juveniles and concluded that FS sustained reasonable weight gain combined with SBM in a $35 \% \mathrm{CP}$ practical diet. They obtained a mean weight gain $(3.5 \pm 0.1 \mathrm{~g})$ similar to that reached in our pond trail $(3.47 \pm 0.16 \mathrm{~g})$, rearing bigger shrimps ( $1.9 \pm 0.03 \mathrm{~g}$ initial weight) in tanks. Specifically, the overall growth results showed that the mixture of the $18.75 \% \mathrm{FS} / 39.75 \% \mathrm{JCK}$ diet can be used to totally substitute FM as the protein source in diets for L. vannamei, since it did not impair shrimp growth performance under both laboratory and pond rearing conditions.

The SGR obtained in the laboratory trial was similar (1.9\%/day) to that reported by Davis and Arnold (2000) for $L$. vannamei reared for 42 days using a mixture of coextruded soybean-poultry byproduct meal in a practical diet, but lower $(3.9 \% /$ day) than the observed by Suárez et al. (2009) for the same species when FM was replaced by soy and canola meals. Differences in results can be attributed to ingredients and proportions used, age of shrimp, culture conditions, and experimental time. The favorable growth response of $L$. vannamei juveniles fed the $18.75 \% \mathrm{FS} / 39.75 \% \mathrm{JCK}$ diet could be partially explained because of its amino acid content which was the only diet fulfilling the amino acid requirements suggested by Tacon et al. (1999), Fox et al. (2010), and Nunes et al. (2014) for formulating a diet for shrimp. Church and Pond (1982) concluded that associative effects among ingredients and/or dietary compounds are a commonly observed phenomenon in formulated feeds. For instance, Samocha et al. (2004) reported better growth and survival performances of L. vannamei when totally replacing FM by a mixture of extruded soybean and poultry byproduct meal supplemented with eggs. It suggests that the amino acid content and balance of the $18.75 \% \mathrm{FS} / 39.75 \% \mathrm{JCK}$ diet promoted a good weight gain and survival of shrimp reared in laboratory and pond conditions, which was similar to the growth obtained for shrimp fed the FM diet. According to Nunes et al. (2014), methionine and lysine are the first limiting amino acids when vegetable and animal byproducts are used in fish and shrimp diets. The dietary methionine and lysine requirements for shrimp range from 0.7 to $0.9 \%$ and 1.6 to $2.1 \%$, respectively (NRC, 2011). All the experimental diets surpassed these ranges, but only the $18.75 \% \mathrm{FS} /$ $39.75 \%$ JCK diet fulfilled the recommended dietary values given by Tacon et al. (1999), Fox et al. (2010), and Nunes et al. (2014). The daily growth rate $(0.1 \mathrm{~g}$ /day $)$ of the marine white shrimp evaluated in laboratory and pond using the FS/JCK meal as protein source was similar $(0.16$, $0.16,0.15$, and $0.13 \mathrm{~g} /$ day) to that obtained by Amaya et al. (2007), Davis et al. (2004), Furtado et al. (2011), and Krummenauer et al. (2011), respectively, feeding $L$. vannamei juveniles with diverse dietary protein sources in tanks and ponds, but inferior to the full potential of such species under outdoor conditions $(0.3 \mathrm{~g} /$ day $)$ reported by Tacon et al. (2002). Differences among the aforementioned works can be attributed to shrimp initial size, culture system, and protein sources in the diet. It is known that the amino acid composition of processed fish silage can vary using different raw materials (Vidotti et al., 2003). Although the FS used in our experiments was prepared with freshwater fish (tilapia residue from filleting), it seems that the overall growth performance of white shrimp juveniles cultured at high salinity (35-38 PSU) in both trials was not affected by the amino acid composition and source, concluding that FS from tilapia waste filleting combined with JCK meal is a beneficial dietary mixture of ingredients for $L$. vannamei juveniles.

It is well accepted that the ability of shrimp to utilize diets with low levels of FM in clear water systems greatly differ from those carried out in ponds (D'Abramo and Castell, 1997), limiting the practical application of the obtained data, unless it is validated under natural conditions (Moss and Divakaran, 1995). The use of net cages in a pond is a very useful tool to overcome an experiment executed in a realistic environment while keeping the assay on a small scale (Moss et al., 2001). In our study, the trend in the growth performance of shrimp fed the $18.75 \% \mathrm{FS} /$ $39.75 \% \mathrm{JCK}$ and RD diets were similar in laboratory and pond conditions since they obtained the highest growth rates $(0.1 \mathrm{~g} /$ day $)$. Besides the tested diets, shrimp capacity to feed on the natural productivity could also partially contribute to the growing results (Leber and Pruder, 1988). Velasco and Lawrence (2000) and Tacon et al. (2002) mentioned that the ability of shrimp to consume microbial organisms and organic matter produced within a pond directly affects its growth and feed utilization compared with a clear-water culture system. Since growth rate was similar between laboratory and pond trials, it seems that the content of experimental diets evaluated in the pond met shrimp dietary requirements without apparent effect 
from the natural food in the pond. Nevertheless, further studies evaluating the contribution and composition of plankton in pond production systems are recommended to determine if the lack of significant difference between $18.75 \% \mathrm{FS} / 39.75 \% \mathrm{JCK}$ and $\mathrm{RD}$ diets in performance indicators was due to a "dampening" effect resultant from extrinsic nutrients and not to the level of FS/JCK included in the diet. The correlation between the dietary inclusion of the alternative protein sources used and the shrimp weight showed that a combined diet of FS and JCK meals at an average of $28.49 / 33.11 \%$, respectively, can totally substitute FM without affecting the growth performance of shrimp.

\section{Conclusions}

A combination of $18.75 \%$ fish silage/39.75\% Jathropa curcas kernel meals as protein source is a potential alternative to effectively substitute fish meal in practical diets for L. vannamei. This happened at the studied ages under both laboratory and pond conditions with the diets sustaining reasonable shrimp growth performance.

\section{Acknowledgments}

Funding was provided by Instituto Politécnico Nacional (SIP-IPN 20120542; 20131517; 20141467), and COFAA and EDI. López-Aguilar, M. R. is a recipient of a master fellowship from CONACYT and Instituto Politécnico Nacional (BEIFI Grant).

\section{References}

Álvarez, J. S.; Hernández-Llamas, A.; Galindo, J.; Fraga, L.; García, T. and Villarreal. H. 2007. Substitution of fishmeal with soybean meal in practical diets for juvenile white shrimp Litopenaeus schmitti (Perez-Farfante, Kensley 1997). Aquaculture Research, 38:689-695. https://doi.org/10.1111/j.1365-2109.2007.01654.x

Amaya, E.; Davis, D. A. and Rouse, D. B. 2007. Replacement of fish meal in practical diets for the Pacific white shrimp (Litopenaeus vannamei) reared under pond conditions. Aquaculture 262:393-401. https://doi.org/10.1016/j.aquaculture.2006.11.015

AOAC - Association of Official Analytical Chemists. 1990. Official methods of analysis of AOAC International. Association of Official Analytical Chemists, Washington, DC.

Azaza, M. S.; Wassim, K.; Mensi, F.; Abdelmouleh, A.; Brini, B. and Kraïem, M. M. 2009. Evaluation of faba beans (Vicia faba L. var. minuta) as a replacement for soybean meal in practical diets of juvenile Nile tilapia Oreochromis niloticus. Aquaculture 287:174-179. https://doi.org/10.1016/j.aquaculture.2008.10.007

Church, D. C. and Pond, W. G. 1982. Basic animal nutrition and feeding. John Wiley and Sons, New York, USA.

D'Abramo, L. R. and Castell, J. D. 1997. Research Methodology. p.3-25. In: Crustacean nutrition advances in world aquaculture.
D'Abramo, C. R.; Conklin, D. E. and Akiyama, D. M., eds. World Aquaculture Society, Baton Rouge, LA, USA.

Davis, D. A. and Arnold, C. R. 2000. Replacement of fish meal in practical diets for the Pacific white shrimp, Litopenaeus vannamei. Aquaculture 185:291-298.

Davis, D. A.; Samocha, T. M.; Bullis, R. A.; Patnaik, S.; Browdy, C. L.; Stokes, A. D. and Atwood, H. L. 2004. Practical diets in Litopenaeus vannamei (Boone, 1931): Working towards organic and/or all plant production diets. p.202-214. In: Cruz Suárez, L. E.; Ricque Marie, D.; Nieto López, M. G.; Villarreal, D.; Scholz, U. and González, M., eds. Avances en Nutrición Acuícola VII. Memorias del VII Simposium Internacional de Nutrición Acuícola Hermosillo, Sonora, México.

De Muylder, E.; Hage, H. and van der Veldel, G. 2008. Binders: Gelatine as alternative for ures formaldehyde and wheat gluten in the production of water stable shrimp feeds. Aquafeed International 11:10-13.

El-Hakim, N. F. A.; El-Gendy, M. O. A. and Salem, M. F. I. 2007. Effect of incorporation of fish silage into diets on growth performance and body composition on Nile tilapia (Oreochromis niloticus). Egyptian Journal of Aquatic Biology and Fisheries 11:101-117.

Fagbenro, A. O. and Jauncey, K. 1993. Chemical and nutritional quality of raw, cooked and salted silages. Food Chemistry 48:331-335.

Fagbenro, A. O. and Jauncey, K. 1998. Physical and nutritional properties of moist fermented fish silage pellets as a protein supplement for tilapia (Oreochromis niloticus). Animal Feed Science and Technology 71:11-18.

Fagbenro, A. O.; Jauncey, K. and Haylor, G. 1994. Nutritive value of diets containing dried lactic acid fermented fish silage and soybean meal for juveniles Oreochromis niloticus and Clarias gariepinus. Aquatic Living Resources 7:79-85. https://doi.org/10.1051/alr:1994010

Fournier, V.; Huelvan, C. and Desbruyeres, E. 2004. Incorporation of a mixture of plant feedstuffs as substitute for fish meal in diets of juvenile turbot (Psetta maxima). Aquaculture 236:451-465. https://doi.org/10.1016/j.aquaculture.2004.01.035

Fox, J. M.; Lawrence, A. L.; Patniak, S.; Forster, I.; Ju, Z. Y. and Dominy, W. 2010. Estimation of feed level of methionine by Litopenaeus vannamei (Boone) using covalently-attached and crystalline sources in low-protein semipurified diets. In: CruzSuarez, L. E.; Ricque-Marie, D.; Tapia-Salazar, M.; NietoLópez, M. G.; Villarreal-Cavazos, D. A.; Gamboa-Delgado, J., eds. Avances en Nutrición Acuícola X - Memorias del Décimo Simposio Internacional de Nutrición Acuícola, San Nicolás de los Garza, N. L., México.

Furtado, P. S.; Poersch, L. H. and Wasielesky Jr., W. 2011. Effect of calcium hydroxide, carbonate and sodium bicarbonate on water quality and zootechnical performance of shrimp Litopenaeus vannamei reared in bio-flocs technology (BFT) systems. Aquaculture 321:130-135.

Gallardo, P.; Gaxiola, G.; Soberano, S.; Taboada, J. G.; Pérez, M.; Rosas, C.; Cuzon, G.; Espinosa, L. G.; Sotelo, A. 2012. Nutritive value of diets containing fish silage for juvenile Litopenaeus vannamei (Boone, 1931). Journal of Science Food and Agriculture 92:2320-2325. https://doi.org/10.1002/jsfa.5632

Haard, N. F. 1992. Control of chemical composition and food quality attributes of cultured fish. Food Research International 25:289-307.

Heras, H.; McLeod, C. A. and Ackman, R. G. 1994. Atlantic dogfish silage vs. herring silage in diets for Atlantic salmon (Salmo salar): growth and sensory elevation of fillets. Aquaculture 125:93-103.

Hernández, C.; Olvera-Novoa, M. A.; Aguilar-Vejar, K.; GonzálezRodríguez, B. and Abdo de la Parra, I. 2008. Partial replacement of fish meal by porcine meat meal in practical diets for Pacific white shrimp (Litopenaeus vannamei). Aquaculture 277:244-250. https://doi.org/10.1016/j.aquaculture.2008.02.016 
Honczaryk, A. and Maeda, L. S. 1998. Crescimento do pirarucu Arapaima gigas, utilizando dieta à base de ensilado biológico de pescado. p.93-100. In: Anais do $10^{\circ}$ Simpósio Brasileiro de Aqüicultura, Recife, Brazil.

Houser, R. H. and Akiyama, D. M. 1997. Feed formulations principles. p.493-519. In: Crustacean nutrition, advances in world aquaculture. D'Abramo, L. R.; Conklin, D. E. and Akiyama, D. M., eds. The World Aquaculture Society, Baton Rouge, LA, USA.

Kaushik, S. J.; Cravedi, J. P.; Lalles, J. P.; Sumpter, J.; Fauconneau, B. and Laroche, M. 1995. Partial or total replacement of fish meal by soybean protein on growth, protein utilization, potential estrogenic or antigenic effects, cholesterolemia and flesh quality in rainbow trout, Oncorhynchus mykiss. Aquaculture 133:257-274.

Krummenauer, D.; Peixoto, S.; Oliveira-Cavalli, R.; Poersch, L. H. and Wasielesky Jr., W. 2011. Superintensive culture of white shrimp, Litopenaeus vannamei, in a biofloc technology system in southern Brazil at different stocking densities. Journal of the World Aquaculture Society 42:726-733.

Kumar, V.; Makkar, H. P. S.; Amselgruber, W. and Becker, K. 2010. Physiological, hematological and histopathological responses in common carp (Cyprinus carpio L.) fingerlings fed with differently detoxified Jatropha curcas kernel meal. Food Chemistry and Toxicology 48:2063-2072. https://doi.org/10.1016/j.fct.2010.05.007

Leber, K. M. and Pruder, G. D. 1988. Using experimental microcosms in shrimp research: The growth-enhancing effect of shrimp pond water. Journal of the World Aquaculture Society 19:197-203. https://doi.org/10.1111/j.1749-7345.1988.tb00780.x

Makkar, H. P. S. and Becker, K. 2009. Jatropha curcas, a promising crop for the generation of biodiesel and value-added co-products. European Journal of Lipid Science and Technology 111:773-787. https://doi.org/10.1002/ejlt.200800244

Makkar, H. P. S.; Siddhuraju, P. and Becker, K. 2007. A laboratory manual on quantification of plant secondary metabolites. Human Press, Totowa, New Jersey, USA.

Makkar, H. P. S.; Martínez-Herrera, J. and Becker, K. 2008. Variations in seed number per fruit, seed physical parameters, and contents of oil, protein, and phorbol ester in toxic and non-toxic genotypes of Jatropha curcas. Journal of Plant Sciences 3:260-265.

Moss, S. M. and Divakaran, S. 1995. Characterization of organic particles associated with rapid growth in juvenile white shrimp, Penaeus vannamei Boone, reared under intensive culture conditions. Journal of Experimental Marine Biology and Ecology 187:175-191.

Moss, S. M.; Divakaran, S. and Kim, B. G. 2001. Stimulating effects of pond water on digestive enzyme activity in the Pacific white shrimp, Litopenaeus vannamei (Boone). Aquaculture Research 32:125-131. https://doi.org/10.1046/j.1365-2109.2001.00540.x

Nepal, S.; Kumar, V.; Makkar, H. P. S. and Becker, K. 2010. Comparative nutritional evaluation of Jatropha curcas protein isolate and soy protein isolate in common carp (Cyprinus carpio L.) fingerlings. European Aquaculture Society, Aquaculture Europe, Porto, Portugal.

NRC - National Research Council. 2011. Nutrient requirements of fish and shrimp. Animal Nutrition Series. The National Academies Press, Washington DC, USA.

Nunes, A. J. P.; Sá, M. V. C.; Browdy, C. L. and Vázquez-Anon, M. 2014. Practical supplementation of shrimp and fish feeds with crystalline amino acids. Aquaculture 431:20-27.
Samocha, T.; Davis, D. A.; Saoud, I. P. and De Bault, K. 2004. Substitution of fish meal by co-extruded soybean poultry byproduct meal in practical diets for the Pacific white shrimp, Litopenaeus vannamei. Aquaculture 231:197-203.

Shamna, N.; Sardar, P.; Sahu, N. P.; Pal, A. K.; Jain, K. K. and Phulia, V. 2015. Nutritional evaluation of fermented Jatropha protein concentrate in Labeo rohita fingerlings. Aquaculture Nutrition 21:33-42. https://doi.org/10.1111/anu.12138

Shearer, K. 2000. Experimental design, statistical analysis and modeling of dietary nutrient requirement studies for fish: a critical review. Aquaculture Nutrition 6:91-102.

Siang, C. C. 2009. Jatropha curcas L.: Development of a new oil crop for biofuel. Available at: $<$ http://eneken.ieej.or.jp/en/data/pdf/467. pdf $>$. Accessed on: 03/20/2017.

Soltan, M. A. and El-Laithy, S. M. 2008. Evaluation of fermented silage made from fish, tomato and potato by-products as a feed ingredient for Nile tilapia, Oreochromis niloticus. Egyptian Journal of Aquatic Biology and Fisheries 12:25-41.

Soltan, M. A. and Tharwat, A. A. 2006. Use of fish silage for partial or complete replacement of fish meal in diets of Nile tilapia (Oreochromis niloticus) and African catfish (Clarias gariepinus). Egyptian Journal of Nutrition and Feeds 9:299-314.

Stone, F. E.; Hardy, R. W.; Shearer, K. D. and Scott, T. M. 1989. Utilization of fish silage by rainbow trout (Salmo gairdneri). Aquaculture 76:109-118.

Suárez, J. A.; Gaxiola, G.; Mendoza, R.; Cadavid, S.; García, G.; Alanis, G.; Suárez, A.; Faillace, J. and Cuzon, G. 2009. Substitution of fish meal with plant protein sources and energy budget for white shrimp Litopenaeus vannamei (Boone, 1931). Aquaculture 289:118-123. https://doi.org/10.1016/j.aquaculture.2009.01.001

Tacon, A. G. J.; Conklin, D. E. and Pruder, G. D. 1999. Shrimp feeds and feeding: at the crossroads of a cultural revolution. Controlled and Biosecure Production Systems: Evolution and Integration of Shrimp and Chicken Models. p.55-66. In: Bullis, R. A. and Pruder, G. D., eds. Proceedings of a Special Session of the World Aquaculture Society Sydney, Australia.

Tacon, A. G. J.; Cody, J. J.; Conquest, L. D.; Divakaran, S.; Foster, I. P. and Decamp, O. E. 2002. Effect of culture system on the nutrition and growth performance of Pacific white shrimp Litopenaeus vannamei (Boone), fed different diets. Aquaculture Nutrition 8:121-137. https://doi.org/10.1046/j.1365-2095.2002.00199.x

Velasco, M. and Lawrence, A. 2000. Initial evaluation of shrimp vitamin requirements in laboratory tanks without water exchange. Global Aquaculture Advocate 3:23.

Viana, M. T.; Guzmán, J. M. and Escobar, R. 1999. Effect of heated and unheated fish silage as protein source in diets for abalone Haliotis fulgens. Journal of the World Aquaculture Society 30:481489. https://doi.org/10.1111/j.1749-7345.1999.tb00996.x

Vidotti, R. M.; Macedo-Villegas, E. M. and Carneiro, D. J. 2003. Amino acid composition of processed fish silage using different raw materials. Animal Feed Science and Technology 105:199-204.

Yue, Y. and Zhou, Q. 2009. Effect of replacing soybean meal with cottonseed meal on growth, feed utilization, and hematological indexes for juvenile hybrid tilapia, Oreochromis niloticus $\times$ O. aureus. Aquaculture 284:185-189.

Zar, J. H. 2010. Biostatistical analysis. Prentice-Hall, Englewood Cliffs, New Jersey, USA. 